\title{
Identification of an unusual Brucella strain (BO2) from a lung biopsy in a 52 year-old patient with chronic destructive pneumonia
}

\author{
Rebekah V Tiller', Jay E Gee ${ }^{1}$, David R Lonsway ${ }^{1}$, Sonali Gribble ${ }^{2,3}$, Scott C Bell ${ }^{2}$, Amy V Jennison ${ }^{4}$, John Bates ${ }^{4}$, \\ Chris Coulter ${ }^{2,3}$, Alex R Hoffmaster ${ }^{1}$, Barun K De
}

\begin{abstract}
Background: Brucellosis is primarily a zoonotic disease caused by Brucella species. There are currently ten Brucella spp. including the recently identified novel $B$. inopinata sp. isolated from a wound associated with a breast implant infection. In this study we report on the identification of an unusual Brucella-like strain (BO2) isolated from a lung biopsy in a 52-year-old patient in Australia with a clinical history of chronic destructive pneumonia.

Results: Standard biochemical profiles confirmed that the unusual strain was a member of the Brucella genus and the full-length $16 \mathrm{~S}$ rRNA gene sequence was $100 \%$ identical to the recently identified B. inopinata sp. nov. (type strain $\mathrm{BO}^{\mathrm{T}} \mathrm{T}$. Additional sequence analysis of the rec $A$, omp2a and $2 b$ genes; and multiple locus sequence analysis (MLSA) demonstrated that strain $\mathrm{BO} 2$ exhibited significant similarity to the B. inopinata sp. compared to any of the other Brucella or Ochrobactrum species. Genotyping based on multiple-locus variable-number tandem repeat analysis (MLVA) established that the $\mathrm{BO} 2$ and $\mathrm{BO}^{\top}$ strains form a distinct phylogenetic cluster separate from the other Brucella spp.
\end{abstract}

Conclusion: Based on these molecular and microbiological characterizations, we propose that the $\mathrm{BO} 2$ strain is a novel lineage of the newly described B. inopinata species.

\section{Background}

Brucellosis is primarily a zoonotic disease, caused by members of the genus Brucella, which currently constitutes several species based on pathogenicity, host preferences and phenotypic characteristics: B. abortus (cattle), B. canis (dogs), B. melitensis (goats), B. suis (pigs), $B$. ovis (rams), B. neotomae (desert rats), B. ceti and B. pinnipedialis (marine mammals), and B. microti (common vole) [1-6]. Recently, a novel species, Brucella inopinata, associated with a human infection has been recognized as the newest member of the genus Brucella $[7,8]$. In early 1985, whole genome hybridization analysis studies revealed a high degree of genetic homology among the Brucella species, which led to the proposal that the genus Brucella was a mono-specific species with $B$. melitensis being the primary species and all others as

\footnotetext{
* Correspondence: bkd1@cdc.gov

'Division of Foodborne, Bacterial, and Mycotic Diseases and Division of Healthcare Quality Promotion, Centers for Disease Control and Prevention, 1600 Clifton Road, Atlanta, GA 30333, USA
}

sub-species and biovars [9-11]. However, due to the limited acceptability of the one-species concept, the traditional classification of Brucella spp. based on phenotypic characteristics has been re-instated by the Brucella Taxonomy Subcommittee in 2006 [3].

Brucella are facultative intracellular pathogens that infect many organs and soft tissues, including mammary glands. Infection frequently results in abortion, low milk production and fetal death in animals [2,12-16]. Brucellosis in humans is mostly caused by $B$. abortus, $B$. melitensis, $B$. suis, and sometimes $B$. canis [14,17-19], and is commonly associated with the consumption of unpasteurized dairy products, meat from infected animals and exposure to infected animal tissues or laboratory transmission $[1,2,20]$. Human brucellosis is a chronic debilitating infection with a very broad clinical picture potentially affecting any major organ, including the lung, causing varying respiratory symptoms [20]. Respiratory infections in humans caused by Brucella spp. is a rare manifestation with reports describing 
multifocal abscesses or nodules, hilar adenopathy and hemorrhagic pleural effusion with resolution by antimicrobial therapy and lung decortications [21-26]. Most pulmonary brucellosis cases were found in farmers handling infected meat or travelers who consumed raw infected animal meat or unpasteurized milk products while visiting countries endemic for brucellosis [26,27].

We report the isolation and identification of an unusual gram-negative, non-motile Brucella-like coccoid bacillus (BO2) isolated from a lung biopsy in a 52-yearold male in Australia with a history of chronic destructive pneumonia. The patient traveled worldwide but denied any common risk factors associated with brucellosis. Both biochemical and molecular characteristics of the BO2 strain have demonstrated unique similarity with a recently described $B$. inopinata strain $\left(\mathrm{BO}^{\mathrm{T}}\right)$ associated with a breast implant wound of a 71-year-old patient from Portland, Oregon with clinical signs of brucellosis $[7,8]$.

\section{Results}

\section{Phenotypic characterization}

BO2 cells grown on SBA or RBA at $35-37^{\circ} \mathrm{C}$ with or without $5 \% \mathrm{CO}_{2}$ for 24 to $48 \mathrm{~h}$ were circular, convex, entire, smooth and opaque. The organisms were gramnegative, generally stained uniformly; and appeared coccoid to short coryneform rods. Colonies of the BO2 strain ranged in size from punctuate to $1.5 \mathrm{~mm}$ in diameter and they were non-motile, mucoid colonies on MacConkey agar; positive for oxidase and catalase, exhibited nitrate reduction with production of gas and rapid urease production $(<5 \mathrm{~min})$. Hydrogen sulfide production by the $\mathrm{BO} 2$ strain was observed by the development of a dark gray color on lead acetate paper suspended above the heart infusion agar slant.
Subculture of individual colony types produced similar profiles and no hemolytic reaction was observed on SBA plates after overnight incubation at $37^{\circ} \mathrm{C}$. The BO2 cells grew in the presence of thionine $(1: 25,000,1: 50,000$ and $1: 100,000$ dilutions) and basic fuchsin (1:50,000 and $1: 100,000$ dilutions) dyes within 24 to $48 \mathrm{~h}$. Both the acriflavin and gel formation tests were negative. However, lysis by Tbilisi phage specific for detection of Brucella spp. in two routine test dilutions ( $1 \times$ and $4 \times$ RTD) appeared incomplete $[7,8,28]$ and agglutination of the BO2 cells with either monospecific anti-M or anti-A antisera were very weak.

\section{Antimicrobial susceptibility test}

The antimicrobial susceptibility profile of the $\mathrm{BO} 2$ strain was compared with a set of 93 other Brucella spp. strains (74 B. melitensis, $14 \mathrm{~B}$. suis and $5 \mathrm{~B}$. abortus) along with $\mathrm{BO} 1^{\mathrm{T}}$ based on CLSI interpretive requirements for Brucella spp. $[8,29,30]$. Both strains had very similar MIC patterns to all Brucella reference strains tested previously $[8,30]$ (Table 1$). \mathrm{BO}^{\mathrm{T}}$ and $\mathrm{BO} 2$ strains grew well in cation-adjusted Mueller-Hinton broth (CAMHB) after just 20 hours of incubation, unlike other Brucella spp. (e.g., B. abortus, B. melitensis, and B. suis) which do not routinely grow very well in CAMHB and require 48 hours of incubation in Brucella broth for MIC testing [30]. Our standard phenotypic characterization, including the antimicrobial susceptibility profiles, suggested that the $\mathrm{BO} 2$ strain more closely resembled the $\mathrm{BO} 1^{\mathrm{T}}$ strain of the B. inopinata sp. than the other classical Brucella spp.

Molecular characterization

Detection of IS711 element by PCR

The Brucella specific insertion sequence (IS711) PCR was performed amplifying an 842-bp repetitive element using BO2 genomic DNA. The IS711 profile observed in

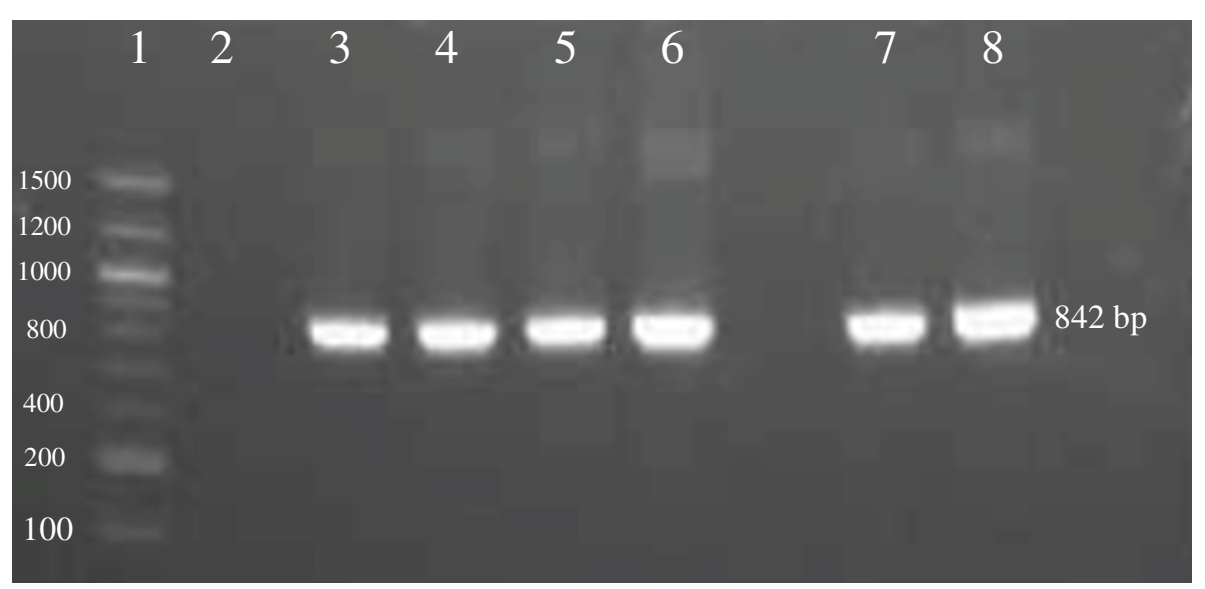

Figure 1 IS711 profiles of PCR amplified products analyzed by gel electrophoresis on a 2\% E-Gel displaying the following: molecular weight marker (lane 1), no template control (lane 2), B. abortus ATCC 23448 (lane 3), B. melitensis 16 M (lane 4), B. suis ATCC 23444 (lane 5), B. ovis ATCC 25840 (lane 6), BO1 ${ }^{\top}$ (lane 7), and BO2 (lane 8). 
strain $\mathrm{BO} 2$ was approximately the same size as that of the $\mathrm{BO}^{\mathrm{T}}$ strain and the classical Brucella spp. including B. ovis (ATCC 25840) (Figure 1). The BO2 strain also generated several large amplicons (>1000 bp) similar to $\mathrm{BO} 1^{\mathrm{T}}$ and other Brucella strains with low intensity as reported earlier [8].

\section{Real-Time PCR for $B O 1^{T} / B O 2$}

A TaqMan PCR assay targeting conserved regions of the $\mathrm{BO} 1^{\mathrm{T}}$ and Brucella spp.16S rRNA gene sequence was designed for rapid differentiation of potential $B$. inopinata-like strains from all other classical Brucella and Ochrobactrum spp. This real-time PCR assay, using two hybridization probes: BI-P specific for B. inopinata spp. and BRU-P specific for Brucella/Ochrobactrum spp., gave average crossing threshold $(\mathrm{Ct})$ values in the range of 15 to 20 (strong positive). The BI-P probe demonstrated perfect agreement for both $\mathrm{BO} 1^{\mathrm{T}}$ and $\mathrm{BO} 2$ strains as did the BRU-P probe for all other Brucella or Ochrobactrum spp. respectively. Both probes showed no cross reactivity against the other non-Brucella strains tested to date [31] demonstrating very high specificity of the target sequences in the PCR assay. Both the $\mathrm{BO} 1^{\mathrm{T}}$ / $\mathrm{BO} 2$ and the Brucella/Ochrobactrum specific probes were capable of optimal detection of template down to $10 \mathrm{fg} / \mu \mathrm{l}$ concentration of genomic DNA template (data not shown).

\section{S rRNA gene sequence analysis}

Rapid identification of the $\mathrm{BO} 2$ strain as B. inopinatalike by the BO1 PCR assay led to sequence analysis of the full-length $16 \mathrm{~S}$ rRNA gene $(1,412 \mathrm{bp})$ of the BO2 strain. Full sequence alignment with the $16 \mathrm{~S}$ rRNA gene sequences of $\mathrm{BO}^{\mathrm{T}}$, reference Orchrobactrum spp. strains, and the Brucella spp. consensus sequence confirmed that the BO2 strain shared 100\% 16S rRNA gene sequence identity to that of $\mathrm{BO}^{\mathrm{T}}$ and $99.6 \%$ identity with other Brucella spp. (Table 2).

\section{Omp $2 a / 2 b$ genes sequence analysis}

We also analyzed two highly homologous outer membrane porin genes (omp2a and $o m p 2 b)$ of the $\mathrm{BO} 2$ and $\mathrm{BO} 1^{\mathrm{T}}$ strains and compared their full-length sequences with that of other Brucella species available in GenBank. The phylogenetic relationships derived by neighbor-joining clustering analysis of the BO2 omp2a (1093 bp) and omp $2 b$ ( 1212 bp) genes with the NCBI sequences of other Brucella strains and the Ochrobactrum anthropi LMG 3331 reference strain demonstrated considerable intra- and inter-species variability (Figure 2). The BO2 omp $2 a$ and $o m p 2 b$ genes are $84.6 \%$ homologous to each other. Neighbor-joining clustering analysis of both $o m p 2 a$ and $o m p 2 b$ nucleotide sequences shows that $\mathrm{BO} 2$ clusters closest to $\mathrm{BO}^{\mathrm{T}}$ and an atypical $B$. suis 83 210 strain [32]. The omp $2 a$ gene of $\mathrm{BO} 2$ is only $1.0 \%$ divergent from that of $\mathrm{BO}^{\mathrm{T}}$. The omp $2 b$ gene is characteristically more diverse within the Brucella spp. and is also evident with the $\mathrm{BO} 2$ omp $2 b$ gene which was 95.3\% and $94.1 \%$ identical to the $\mathrm{BO}^{\mathrm{T}}$ and $B$. suis 83 210 strains, respectively (Figure 2, Table 2). Clustering analysis demonstrates that $\mathrm{BO} 1^{\mathrm{T}}, \mathrm{BO} 2$ and the $B$. suis 83-210 strains form consistent sub-groups based on their omp2a and omp2b gene homology [32].

\section{RecA gene sequence analysis}

The $r e c A$ gene (948 bp) of strain $\mathrm{BO} 2$ was compared to those of $\mathrm{BO}^{\mathrm{T}}$, the classical Brucella spp. $(\mathrm{n}=8)$ and several representative Ochrobactrum spp. [31,33]. Within the genus Brucella, the recA gene is highly conserved with $100 \%$ nucleotide sequence identity among the different species. Interestingly, the $\mathrm{BO} 2 \mathrm{rec} A$ nucleotide sequence reveals $99.2 \%$ identity to the Brucella consensus rec $A$ sequence due to 8 nucleotide substitutions. However, the $\mathrm{BO} 2 \operatorname{rec} A$ gene has a lower identity (98.2\%) when compared to the $\mathrm{BO}^{\mathrm{T}} \operatorname{rec} A$ sequence differing by 17 nucleotides. Phylogenetic analysis of $\mathrm{BO}^{\mathrm{T}}$ and BO2 strains with other Brucella and Ochrobactrum spp. shows that the Brucella spp. clade including BO2 and $\mathrm{BO} 1^{\mathrm{T}}$, are distantly similar to the Ochrobactrum spp. with approximately $85 \%$ sequence identity (Figure 3).

\section{Multiple Locus Sequence Analysis}

Multiple locus sequence analysis (MLSA) of nine Brucella spp. house-keeping genes has been used to

Table 1 MIC results for 5 antimicrobial agents tested against $\mathrm{BO}^{\top}{ }^{\mathrm{T}}, \mathrm{BO} 2$ strains and 93 Brucella strains

\begin{tabular}{|c|c|c|c|c|c|c|c|c|}
\hline & \multicolumn{3}{|c|}{$\mathrm{BO}^{\top} \mathrm{MIC}(\mu \mathrm{g} / \mathrm{ml})$} & \multicolumn{3}{|c|}{ BO2 MIC $(\mu \mathrm{g} / \mathrm{ml})$} & \multicolumn{2}{|c|}{$\begin{array}{c}\text { Brucella spp. }{ }^{a} \text { in Brucella } \\
\text { broth } 48 \mathrm{~h}\end{array}$} \\
\hline & $\mathrm{CAMHB}^{\mathrm{b}}$ & Brucella Broth & Brucella Broth & CAMHB & Brucella Broth & Brucella Broth & MIC Range & $\mathrm{MIC}_{90}$ \\
\hline Antimicrobial agent & $20 \mathrm{~h}$ & $20 \mathrm{~h}$ & $48 \mathrm{~h}$ & $20 \mathrm{~h}$ & $20 \mathrm{~h}$ & $48 \mathrm{~h}$ & $(\mu \mathrm{g} / \mathrm{ml})$ & $(\mu \mathrm{g} / \mathrm{ml})$ \\
\hline Doxycycline & 0.25 & 0.25 & 0.5 & 0.25 & 0.25 & 0.5 & $0.06-1$ & 0.25 \\
\hline Gentamicin & 1 & 2 & 2 & 1 & 2 & 2 & $0.5-2$ & 1 \\
\hline Streptomycin & 4 & 4 & 4 & 2 & 4 & 4 & $1-8$ & 4 \\
\hline Tetracycline & 0.25 & 0.5 & 1 & 0.12 & 0.25 & 0.25 & $0.12-1$ & 0.5 \\
\hline $\begin{array}{l}\text { Trimethoprim- } \\
\text { sulfamethoxazole }\end{array}$ & $0.5 / 9.5$ & $0.25 / 4.75$ & $0.5 / 9.50 .25$ & $0.5 / 9.5$ & $0.25 / 4.75$ & $0.5 / 9.5$ & $0.12 / 2.38-0.5 / 9.5$ & $0.5 / 9.5$ \\
\hline
\end{tabular}

${ }^{a}$ Ninety-three Brucella isolates (74 B. meli1tensis, 14 B. suis, and 5 B. abortus) were tested [30].

${ }^{b} \mathrm{CAMHB}=$ cation-adjusted Mueller-Hinton broth. 
Table 2 Comparative percent identity based on pair-wise analysis of five genes of $\mathrm{BO} 2$ with $\mathrm{BO}^{\mathrm{T}}$ and classical Brucella spp. using MEGA4.

\begin{tabular}{ccc}
\hline BO2 genes & B. inopinata BO1 $^{\boldsymbol{\top}}$ (\%) & Brucella spp. (\%) \\
\hline 16S rRNA & 100.0 & 99.6 \\
RecA & 98.2 & 99.2 \\
MLSA & 98.7 & $98.3-98.6$ \\
Omp2a & 99.0 & $85.4-98.4$ \\
Omp2b & 95.3 & $83.8-95.3$ \\
\hline
\end{tabular}

differentiate Brucella spp. into distinct sequence types (ST). $\mathrm{BO}^{\mathrm{T}}$ was determined to be $1.67 \%$ divergent from ST1 and to possess novel alleles at all nine loci [8]. $\mathrm{BO} 2$ has shown similar divergence $(1.5 \%)$ from ST1 by MLSA also with novel alleles in all nine loci. Neighbor-joining phylogenetic analysis clearly shows how divergent the $\mathrm{BO} 1^{\mathrm{T}}$ and $\mathrm{BO} 2$ species are from the classical Brucella sequence types (Figure 4). Throughout the 4,396-bp sequence examined, the $\mathrm{BO}^{\mathrm{T}}$ and $\mathrm{BO} 2$ genomes have 32 common SNPs while there are $30 \mathrm{BO}^{\mathrm{T}}$ and $26 \mathrm{BO} 2$ specific nucleotide changes that further characterize the divergence of these two strains at these highly conserved loci in the Brucella genus.

\section{Multiple-Locus Variable-Number Tandem Repeat Analyses} Both $\mathrm{BO} 2$ and $\mathrm{BO}^{\mathrm{T}}$ strains were also investigated by multiple-locus variable-number tandem repeat (VNTR) analysis (MLVA) using fifteen VNTR loci by capillary electrophoresis. Results were compared with a panel of well-characterized Brucella strains $(\mathrm{n}=209)$ representing known species from our collection [31]. Our MLVA-15 typing analysis of both $\mathrm{BO} 2$ and $\mathrm{BO}^{\mathrm{T}}$ strains demonstrated unique VNTR profiles in which both strains have six Brucella-loci with the same alleles (VNTR 2, -3, -14, -20,-21 and -25); and seven loci with variable VNTR amplicons (VNTR1, -7, -27, -29, -30, -31 and -33). All VNTRs successfully amplified in both $\mathrm{BO} 1$ and $\mathrm{BO} 2$ with the exception of VNTR16 and -28 in $\mathrm{BO}^{\mathrm{T}}$. MLVA-15 analysis revealed that both $\mathrm{BO} 2$ and $\mathrm{BO}^{\mathrm{T}}$ had distinct VNTR profiles in comparison to each other and other Brucella strains (Figure 5).

\section{Discussion}

In this paper we present the identification of an atypical Brucella-like strain (BO2) isolated from the lung biopsy of a 52-year-old patient. As a young adult he lived in Oregon on two occasions (1981 and 1985-1987), and experienced an unexplained 'liver failure' and then severe pneumonia (with pleurisy) from which he recovered with multiple courses of antimicrobial therapy as reported by the patient to his physicians in Australia. This patient was originally misdiagnosed because of the misidentification of the $\mathrm{BO} 2$ strain as $O$. anthropi on an AP1 20NE system. It is a common practice for clinical labs to attempt rapid identification of gram-negative $c o c$ cobacillus organisms like Brucella spp. from blood culture using automated systems. However, the Brucella spp. are often misidentified due to their similar phenotypic characteristics to closely related organisms such as Ochrobactrum spp. $[34,35]$. Though the patient was initially treated for both Ochrobactrum and Brucella infections due to the difficulties in diagnosis, he recovered with an extended course of combination oral antimicrobial therapy.

This BO2 strain is phenotypically and molecularly similar to the recently identified $B$. inopinata type strain $\left(\mathrm{BO}^{\mathrm{T}}\right)$ recovered from a patient from Oregon, which was also originally misidentified as $O$. anthropi by the API 20E and API 20NE $[7,8]$. Both these strains share common colony morphology and biochemical characteristics including rapid urease and positive $\mathrm{H}_{2} \mathrm{~S}$ production, inability or very weak agglutination with Brucella specific antisera for the lipopolysaccharide-O-antigens or acriflavin. Neither the $\mathrm{BO}^{\mathrm{T}}$ or $\mathrm{BO} 2$ strains supports gel formation or exhibits growth inhibition to the dye media as shown by common members of the genus Brucella. $\mathrm{BO} 2$ also exhibited incomplete lysis by Tbilisi phage and had very similar antimicrobial susceptibility profiles to $\mathrm{BO}^{\mathrm{T}}$ in comparison to other Brucella reference strains.

Insertion sequence (IS) fingerprinting in the Brucella species has shown that the genomic localization and copy number of the IS711 insertion element (also called IS6501) is species-specific and could have an association with specific pathogenicity for a preferred host [36-38]. The presence of multiple copies of $\mathrm{BO}^{\mathrm{T}}$-like IS711 insertion sequences suggest not only that $\mathrm{BO} 2$ is a member of the Brucella genus (Figure 1) but that the BO2-IS711 amplification pattern specifically resembles that of the newly described B. inopinata species [8]. Positive identification of the $\mathrm{BO} 2$ strain as a member of B. inopinata by our real-time BO1 PCR assay was significant. Both $\mathrm{BO}^{\mathrm{T}}$ and $\mathrm{BO} 2$ strains were the cause of distinct and unusual forms of human brucellosis. Atypical clinical isolates of this nature can often be misdiagnosed by automated systems as was the case with $\mathrm{BO}^{\mathrm{T}}$ and the $\mathrm{BO} 2$ strain described here $[8,35]$. The availability of the real-time TaqMan assay served as a reliable first-line tool for determining B. inopinata-like species.

These initial findings led to further characterization and sequence-based typing which provided additional supporting evidence that this new $\mathrm{BO} 2$ strain most resembles the $B$. inopinata sp. within the Brucella genus. Using broad-range eubacterial primers, Gee $e t$. al. effectively demonstrated the advantage of $16 \mathrm{~S}$ rRNA gene sequencing to identify Brucella isolates reporting $100 \%$ identity in all the strains examined [31]. Interestingly, the full-length 16S rRNA gene sequence of $\mathrm{BO} 2$ 


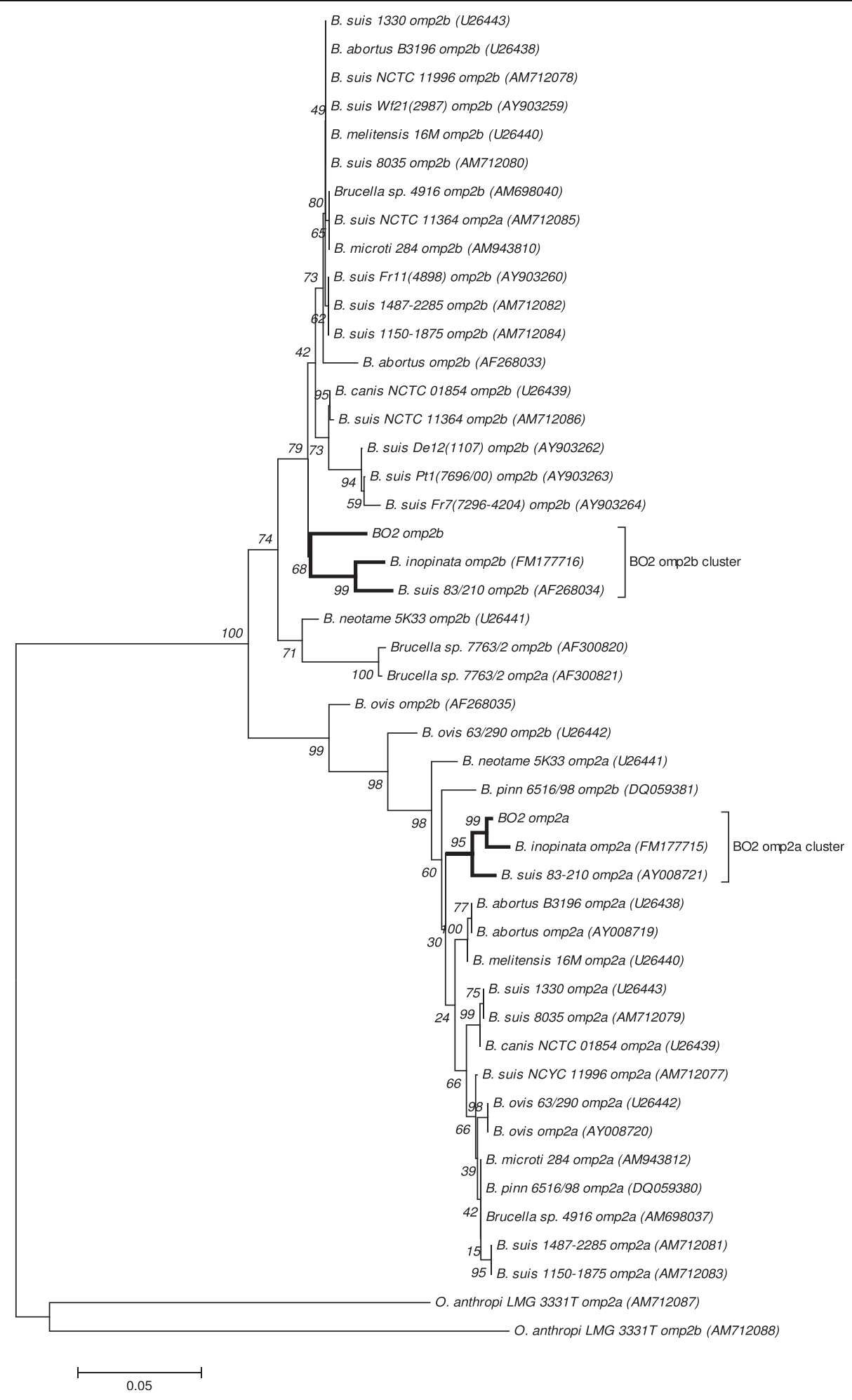

Figure 2 Phylogenetic tree reconstructed with omp2a (1093 bp) and omp2b ( 1211 bp) sequences using MEGA v.4.0 neighbor joining analysis. The bootstrap consensus tree inferred from 1000 replicates is taken to represent the evolutionary history of the taxa analyzed. The significance of each branch is indicated by a bootstrap percentage calculated from 1000 replicates. 


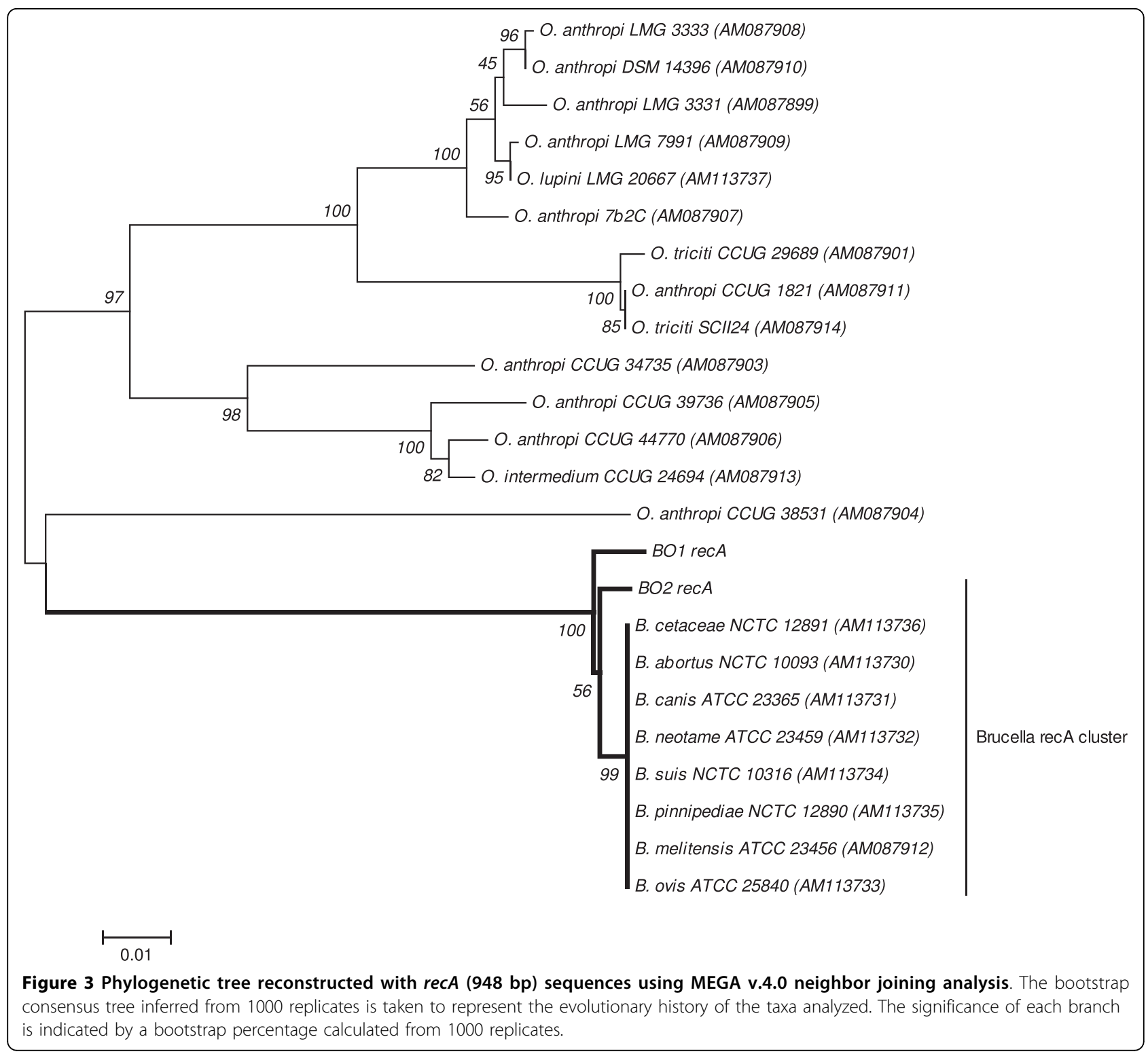

was $100 \%$ identical to that of $\mathrm{BO}^{\mathrm{T}}$ and $99.6 \%$ identical to the Brucella spp. consensus 16S rRNA gene sequence. The high sequence identity of the $\mathrm{BO} 216 \mathrm{~S}$ rRNA sequence to the recently described $B$. inopinata sp. is remarkable and represents the first recognized Brucella species to have a divergent $16 \mathrm{~S}$ rRNA sequence [8].

The recA gene has been investigated as an alternative phylogenetic marker for several bacterial genera due to its highly conserved nature and ubiquity in prokaryotes $[33,39,40]$. Unlike the high sequence homology of the recA gene within the Brucella genus [41], we identified unique variability in the $r e c A$ gene sequences of $\mathrm{BO} 2$ and $\mathrm{BO}^{\mathrm{T}}$. Sequence analysis revealed that the $\operatorname{rec} A$ nucleotide sequence of the $\mathrm{BO} 2$ strain shared greater similarity with the Brucella spp. recA consensus sequence than to $\mathrm{BO}^{\mathrm{T}}$. Both $\mathrm{BO} 2$ and $\mathrm{BO}^{\mathrm{T}}$ rec $\mathrm{A}$ sequences are distanced by 8 and 11 unique SNPs, respectively, from the Brucella spp. recA consensus sequence, and share only one common transversion at the 517 nucleotide position. Translation of the $\operatorname{rec} A$ gene sequences of $\mathrm{BO}^{\mathrm{T}}, \mathrm{BO} 2$ and the Brucella spp. consensus sequence shows that all base pair changes were synonymous substitutions having no effect on protein structure or function. The Brucella outer membrane proteins have been studied extensively for their function in virulence, pathogenicity, bacteriophage reception, antigenic factors and antibacterial evasion [42-45]. The genetic variability among the omp genes within the Brucella spp. has proven effective at 


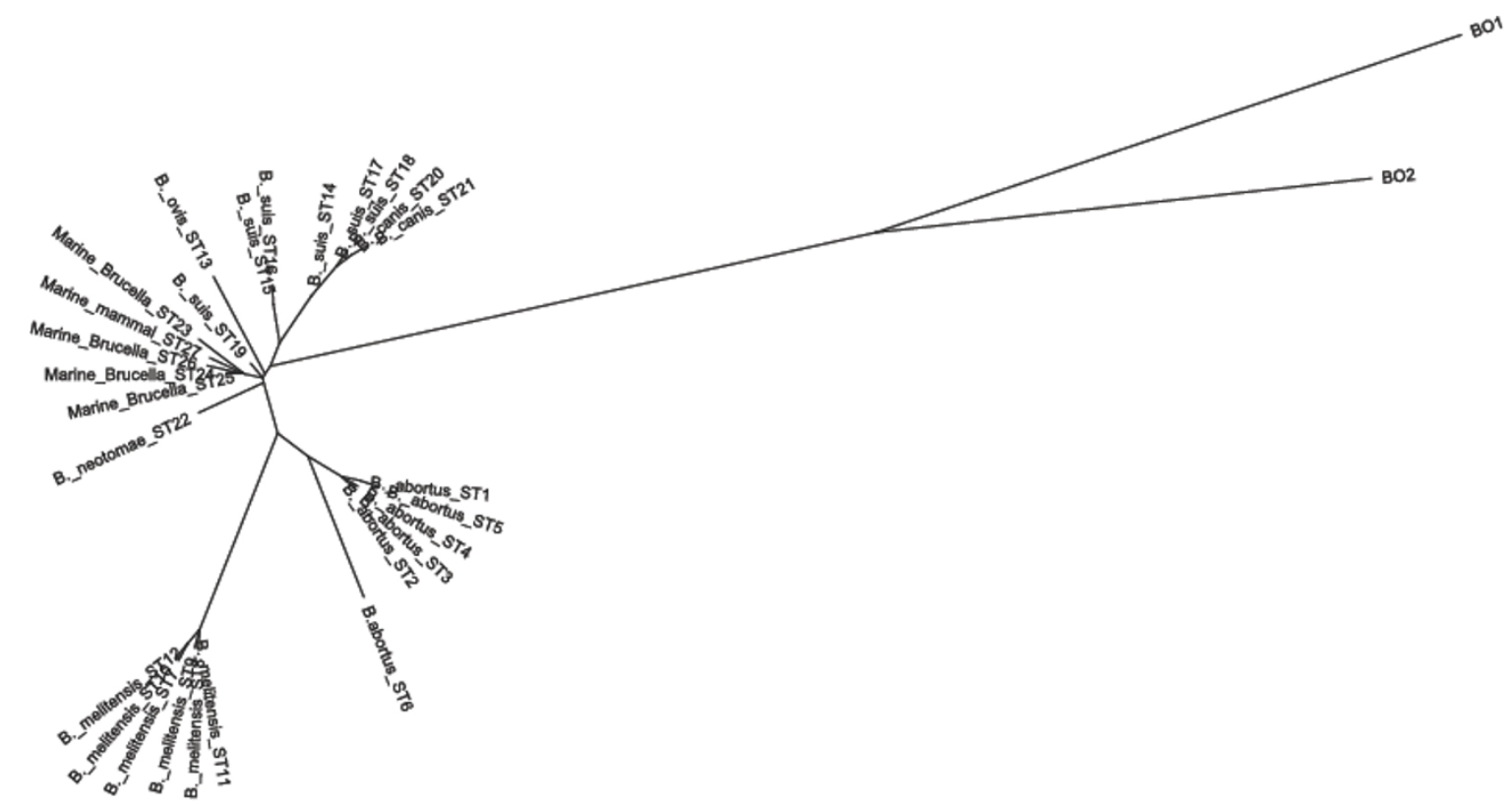

0.0020

Figure 4 Unrooted phylogenetic reconstruction of the concatenated sequences of nine house-keeping genes (4,396 bp) using the neighbor-joining approach. Represented are the 27 known Brucella sequence types along with $\mathrm{BO}^{\top}$ and their relation to $\mathrm{BO} 2$.

characterizing Brucella spp. and strain types and is often used for higher resolution molecular typing $[4,32,43,45]$. The $o m p 2 a / 2 b$ genetic analysis we report here is very interesting in that $\mathrm{BO} 2$ consistently associates with not only $\mathrm{BO} 1^{\mathrm{T}}$ but the atypical $B$. suis $83-210$ strain that was isolated from a rodent in Australia [32]; and thus further investigation may be warranted into rodents as a possible natural reservoir for these novel Brucella species.

Investigation of the nine housekeeping genes by multi locus sequencing analysis demonstrates that $\mathrm{BO} 2$ is genetically distinct from $\mathrm{BO}^{\mathrm{T}}$ yet exhibits remarkably similar divergence (1.5\%) from the classical Brucella sequence types as shown in Figure 4. The relative similarity of the nucleotide sequences of $\mathrm{BO}^{\mathrm{T}}$ and $\mathrm{BO} 2$ by MLSA demonstrates uniquely distant sequence types within the currently characterized Brucella spp. and should be considered as a new group of STs within the Brucella genus. They also exhibit distinct allelic profiles by MLVA although all alleles in both the $\mathrm{BO}^{\mathrm{T}}$ and $\mathrm{BO} 2$ allelic profiles have been observed in other Brucella spp. Furthermore, the phylogenetic analysis shown in Figure 5 demonstrates that these strains form a single separate cluster from the classical Brucella spp. [8].

The molecular and microbiological characteristics presented here provide supporting evidence that strain $\mathrm{BO} 2$ is most closely associated with the $\mathrm{BO} 1^{\mathrm{T}}$ strain and should be considered as a novel lineage of B. inopinata sp. Attempting to understand the evolutionary origin of these two strains is somewhat confounded by the interesting and disparate medical histories of the case patients (who both happened to have lived in Portland, Oregon) from whom these strains were isolated and suggests that there are new and emerging Brucella strains capable of causing unusual presentation of human brucellosis.

\section{Conclusion}

Phenotypic and genomic analysis of the unusual Brucella strain (BO2) from a lung biopsy have established it as a lineage of the recently identified novel $B$. inopinata sp. type strain $\mathrm{BO} 1^{\mathrm{T}}$, which was isolated from a wound associated with a breast implant. This is the first report of a human brucellosis case associated with chronic destructive pneumonia caused by an atypical Brucella strain. An interesting finding from our molecular analysis reveals that both strains $\mathrm{BO}^{\mathrm{T}}$ and $\mathrm{BO} 2$ appeared to be closely related to a less-characterized $B$. suis strain 83-210 (isolated from a rodent in Australia) by their omp $2 a / 2 b$ genes, which may suggest a common ancestor and may also provide insight into the ecological niche, and host reservoir for these novel Brucella strains causing unusual human infections. 


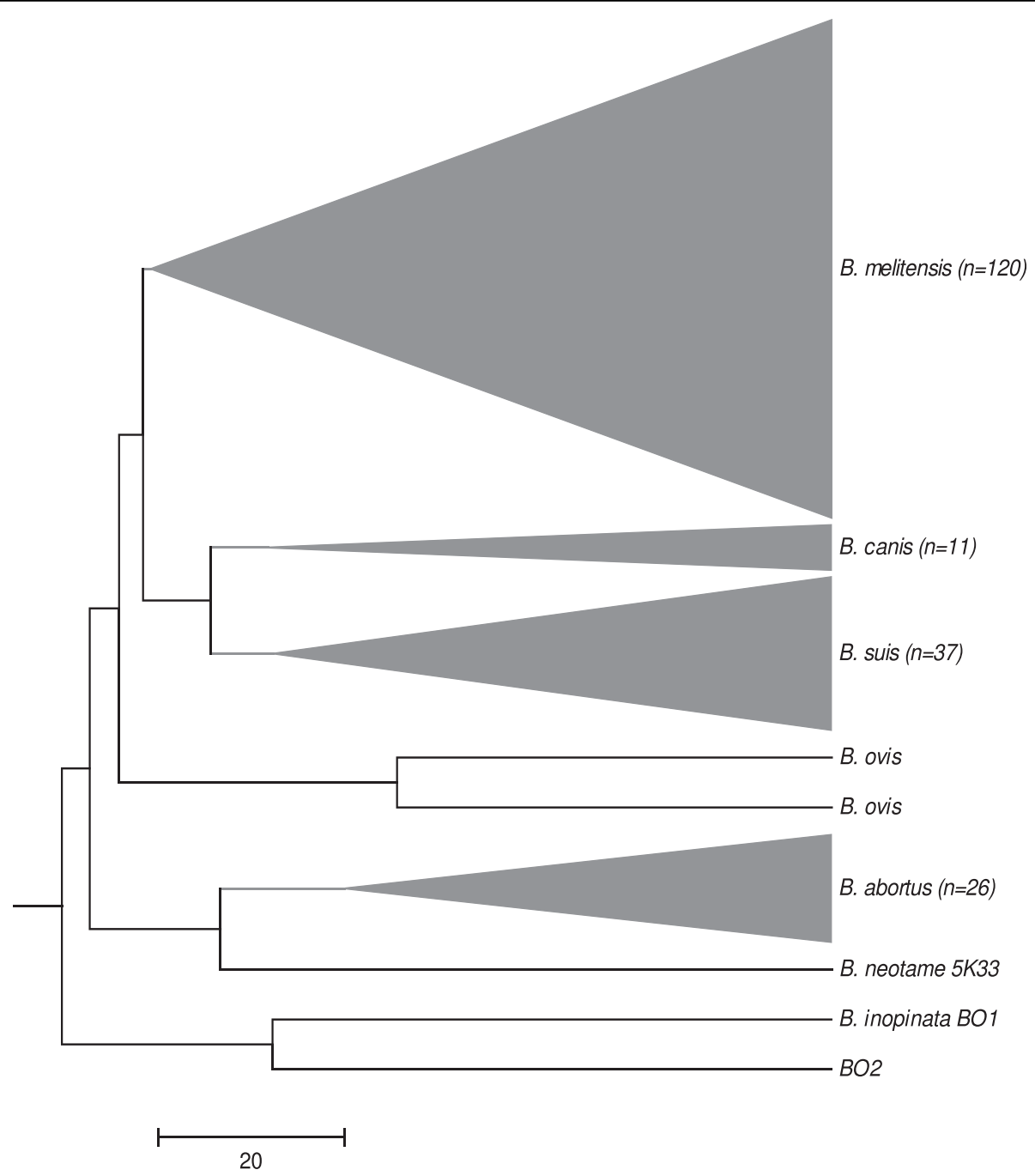

Figure 5 Condensed unweighted pair group method analysis (UPGMA) dendogram of multiple-locus variable number tandem repeat analysis (MLVA) genotypes of $\mathrm{BO}^{\top}{ }^{\top}, \mathrm{BO} 2$ strains along with 209 characterized Brucella strains.

\section{Methods}

\section{Patient}

The patient was born in Malta in 1956 and immigrated to Australia at age two, where he would continually return and eventually settle throughout extensive worldwide travel including the Western region of the United States. Between 2003 and 2007, the patient was hospitalized multiple times in different hospitals in Australia for abnormal liver function, community acquired pneumonia, anterior chest wall abscess and sinus infection. In September 2007 a percutaneous lung biopsy was performed and a gram-negative organism was isolated from a broth culture of the fine needle aspirate of the patient's lung and identified as Ochrobactrum anthropi on an API20NE system. The testing laboratory was aware of the possibility of Brucella sp. being misidentified as Ochrobactrum anthropi [35] and the isolate was referred for further testing. The patient was treated with combination therapy of doxycycline and rifampicin for twelve months and ciprofloxacin for three months (the latter was ceased after molecular testing confirmed Brucella species). The culture was initially tested according to standard microbiological and molecular procedures and then forwarded to the Centers for Disease Control and Prevention (CDC), Atlanta, GA, for further characterization. This gram-negative organism was designated as $\mathrm{BO} 2$ and stored at $-70^{\circ} \mathrm{C}$ in defibrinated rabbit blood until further evaluation.

\section{Phenotypic analysis}

The $\mathrm{BO} 2$ strain was routinely maintained on Trypticase soy agar with $5 \%$ defribinated sheep blood agar (SBA) or rabbit blood agar (RBA) (BBL Microbiology Systems, Cockeysville, MD). Phenotypic identification of the $\mathrm{BO} 2$ strain was performed according to the laboratory 
techniques in brucellosis described by Alton et. al. in the World Health Organization monogram [7,8,28].

\section{Antimicrobial susceptibility analysis}

The antimicrobial susceptibility testing of the $\mathrm{BO} 2$ strain was performed by the broth microdilution method in CAMHB and Brucella broth in accordance with the Clinical and Laboratory Standards Institute (CLSI) protocol as described previously $[8,29]$

\section{Molecular analysis}

\section{Detection of IS711}

To detect the Brucella-specific insertion sequence IS711 element (842 bp) [37], cell lysate DNA templates from strains $\mathrm{BO} 2, \mathrm{BO}^{\mathrm{T}}$, B. abortus (ATCC 23448), B. suis 1330 (ATCC 23444), B. ovis (ATCC 25840) and B. melitensis $16 \mathrm{M}$ (ATCC 23456) were amplified and the amplicons were analyzed by $2 \%$ E-Gel agarose gel electrophoresis as mentioned previously [8].

\section{Real-Time PCR assay}

A real-time TaqMan PCR assay was developed targeting a four base nucleotide substitution within the $16 \mathrm{~S}$ rRNA gene sequence of $\mathrm{BO}^{\mathrm{T}}$ (positions 145 to 148; GenBank accession no. EU053207). We designed two PCR primers16SF (5'-CGGGCCGATCATTTGC-3') and16SR (5'-AACTCAGGGAAACTTGTGCTAATACC-3') to amplify a 72 -bp region of the $16 \mathrm{~S}$ rRNA Brucella consensus sequence and two hybridization probes, BI-P (5'AAATCTTTCCCCTTTCGGGCAC-3') and BRU-P (5'AAATCTTTCCCCCGAAGGGCAC-3'), targeting a 4-bp polymorphic region within the $72-\mathrm{bp}$ amplicon. Both probes were synthesized with a 6-carboxyfluorescein reporter molecule attached at the 5 ' end and Black Hole Quencher 1 on the 3' end. Each final PCR reaction mix contained $2 \mu \mathrm{l}$ of DNA template and $18 \mu \mathrm{l}$ of PCR master mixture containing $1 \times$ LightCycler Faststart DNA Master HybProbe mix (Roche Applied Sciences, Indianapolis, IN), $4 \mathrm{mM} \mathrm{MgCl}_{2}, 0.4 \mu \mathrm{M}$ of each primer and $0.2 \mu \mathrm{M}$ of probe. The LightCycler thermal cycling conditions were $95^{\circ} \mathrm{C}$ for $8 \mathrm{~min}$ followed by 45 cycles of $95^{\circ}$ $\mathrm{C}$ for $5 \mathrm{sec}$ and $60^{\circ} \mathrm{C}$ for $5 \mathrm{sec}$ ending in a $45^{\circ} \mathrm{C}$ hold for $1 \mathrm{~min} 15 \mathrm{sec}$. A panel of 54 well characterized Brucella strains and 28 near-neighbors, including 5 Ochrobactrum strains [31] were evaluated by the assay. Positive results are expressed in log scale as crossing threshold values $(\mathrm{Ct})$ of fluorescence released above the no-template control baseline of 0.01 following each amplification as described by the manufacturer.

\section{5 rRNA gene analysis}

The full length amplicon of $16 \mathrm{~S}$ rRNA gene was generated using the BO2 cell-lysate DNA and sequenced using the BigDye terminator cycle 3.1 sequencing kit (ABI, Foster City, CA) as described previously [31]. A comparative full-length sequence analysis of $\mathrm{BO} 2$ was performed with the consensus $16 \mathrm{~S}$ rRNA gene sequence of Brucella spp. [31], and the Ochrobactrum intermedium type strain (GeneBank accession no. AM114411T) along with that of the B. inopinata $B O 1^{\mathrm{T}}$ strain (GeneBank accession no. EU053207) using the GCG Wisconsin software package (version 10.2; Accelrys, San Diego, CA) and MEGA 4.0 [31,46].

\section{Omp2a/2b and recA genes analysis}

The full-length outer membrane porin genes omp $2 a$ and $o m p 2 b$, and also the $\operatorname{rec} A$ gene of $\mathrm{BO} 2$ were sequenced $[33,45]$, and compared with sequences of $\mathrm{BO}^{\mathrm{T}}$ and other Brucella and Ochrobactrum spp. available in GenBank. Contigs were assembled and edited before multiple sequence alignments were constructed in the DNASTAR Lasergene 8 genetic analysis software suite (DNASTAR Inc., Madison, WI). Neighbor-joining consensus trees inferred from 1000 bootstrap replicates were constructed using MEGA version 4.0 [46].

\section{MLSA typing}

To assess the relation of $\mathrm{BO} 2$ with other classical Brucella spp. and $\mathrm{BO}^{\mathrm{T}}$, the multi locus sequence analysis (MLSA) primer sets were used to amplify and sequence nine discrete house-keeping genes as described previously [47]. Multiple sequences were aligned and neighbor-joining phylogenetic trees were constructed as described above.

\section{Sequence identities}

Similarity values reported throughout the text and in Table 2 were calculated from estimates of evolutionary divergence between the sequences represented in the corresponding dendograms. All results are based on the pairwise analysis of inclusive sequences using the Maximum Composite Likelihood method in MEGA 4.0 [46]. All positions containing gaps and missing data were eliminated from the dataset.

\section{MLVA typing}

Molecular typing of the BO2 strain based on multiplelocus variable-number tandem repeat (VNTR) analysis (MLVA) was investigated by examining fifteen Brucella spp. VNTR genetic markers (MLVA-15) [48,49], and a distance tree was generated in BioNumerics v.5.1 (Applied Maths, Saint-Martens-Latem, Belgium) by clustering analysis using the unweighted-pair group method with arithmetic averages (UPGMA) and saved in newick format. Tree manipulations and labeling were done in MEGA 4.0 [46].

\section{Acknowledgements}

The authors thank Dr. Paul Laird of Lismore Base Hospital, Australia, who referred the patient for further assessment after initial investigation and Dr. Richard Slaughter of the Prince Charles Hospital, Australia for careful assessment of the serial $\mathrm{CT}$ scans and for performing the lung biopsy. Written consent was obtained from the patient for publication of the patient's details.

\section{Author details}

${ }^{1}$ Division of Foodborne, Bacterial, and Mycotic Diseases and Division of Healthcare Quality Promotion, Centers for Disease Control and Prevention, 1600 Clifton Road, Atlanta, GA 30333, USA. ${ }^{2}$ Infection Management Service 
and Microbiology, The Prince Charles Hospital, Rode Road Chermside, Queensland 4032, Australia. ${ }^{3}$ Pathology Queensland Central Laboratory, Roya Brisbane and Women's Hospital, Herston Road, Queensland 4029, Australia. ${ }^{4}$ Clinical and Statewide Services Division, Queensland Health, 39 Kessels Road, Coopers Plains, Queensland 4108, Australia.

\section{Authors' contributions}

SG, SCB, AJ, JB CC participated in the clinical diagnosis, isolation and initial characterization of the strain $\mathrm{BO} 2$ and also contributed in drafting the manuscript. RVT, JEG, DRL, ARH, BKD performed both biochemical and molecular studies and drafted the manuscript. All authors read and approved the final manuscript.

\section{Received: 25 August 2009}

Accepted: 27 January 2010 Published: 27 January 2010

\section{References}

1. Boschiroli ML, Foulongne V, O'Callaghan D: Brucellosis: a worldwide zoonosis. Curr Opin Microbiol 2001, 4(1):58-64.

2. Corbel MJ: Brucellosis: an overview. Emerg Infect Dis 1997, 3(2):213-221.

3. Osterman B, Moriyon I: International Committee on Systematics of Prokaryotes; Subcommittee on the taxonomy of Brucella: Minutes of the meeting, 17 September 2003, Pamplona, Spain. Int J Syst Evol Microbiol 2006, 56:1175.

4. Cloeckaert A, Verger JM, Grayon M, Paquet JY, Garin-Bastuji B, Foster G, Godfroid J: Classification of Brucella spp. isolated from marine mammals by DNA polymorphism at the omp2 locus. Microbes Infect 2001, 3(9):729-738.

5. Jahans KL, Foster G, Broughton ES: The characterisation of Brucella strains isolated from marine mammals. Vet Microbiol 1997, 57(4):373-382.

6. Scholz HC, Hubalek Z, Sedlacek I, Vergnaud G, Tomaso H, Al Dahouk S, Melzer F, Kampfer P, Neubauer $H$, Cloeckaert A, et al: Brucella microti sp. nov., isolated from the common vole Microtus arvalis. Int I Syst Evol Microbiol 2008, 58(Pt 2):375-382.

7. Scholz HC, Nockler K, Gollner C, Bahn P, Vergnaud G, Tomaso H, Al Dahouk S, Kampfer P, Cloeckaert A, Maquart M, et al: Brucella inopinata sp. nov., isolated from a breast implant infection. Int I Syst Evol Microbiol.

8. De BK, Stauffer L, Koylass MS, Sharp SE, Gee JE, Helsel LO, Steigerwalt AG, Vega R, Clark TA, Daneshvar Ml, et al: Novel Brucella strain (BO1) associated with a prosthetic breast implant infection. $J$ Clin Microbiol 2008, 46(1):43-49.

9. Verger JM, Grimont F, Grimont PAD, Grayon M: Brucella, a monospecific genus as shown by deoxyribonucleic acid hybridization. Int J Syst Evol Microbiol 1985, 35:292-295.

10. Verger JM, Grimont F, Grimont PA, Grayon M: Taxonomy of the genus Brucella. Ann Inst Pasteur Microbiol 1987, 138(2):235-238.

11. Grimont F, Verger JM, Cornelis P, Limet J, Lefevre M, Grayon M, Regnault B, Van Broeck J, Grimont PA: Molecular typing of Brucella with cloned DNA probes. Res Microbiol 1992, 143(1):55-65.

12. Cerri D, Ebani W, Pedrini A, Nuvoloni R, Renzoni G, Andreani E, Farina R: Epididymitis by Brucella ovis: experimental infection in virgin ram lambs. New Microbiol 1999, 22(3):227-231.

13. Davis CE, Troy SB: Brucellosis. N Engl J Med 2005, 353(10):1071-1072, author reply 1071-1072.

14. Fenkci V, Cevrioglu S, Yilmazer M: Ovarian abscess due to Brucella melitensis. Scand J Infect Dis 2003, 35(10):762-763.

15. Pappas G, Akritidis N, Bosilkovski M, Tsianos E: Brucellosis. N Engl J Med 2005, 352(22):2325-2336.

16. Troy SB, Rickman LS, Davis CE: Brucellosis in San Diego: epidemiology and species-related differences in acute clinical presentations. Medicine (Baltimore) 2005, 84(3):174-187.

17. El-Olemy GM, Atta AA, Mahmoud WH, Hamzah EG: Brucellosis in man-II. Isolation of the causative organisms with special reference to blood picture and urine constituents. Dev Biol Stand 1984, 56:573-578.

18. El-Olemy GM, Atta AA, Mahmoud WH, Hamzah EG: Brucellosis in man. I. Serological diagnosis. Dev Biol Stand 1984, 56:565-572

19. Quaife RA: Brucellosis in man. J Med Lab Technol 1969, 26(4):349-357.

20. Corbel MJ: Recent advances in brucellosis. J Med Microbiol 1997, 46(2):101-103.

21. Al-Anazi AR, Aziz S, Fouda MA: Brucellosis: haemorrhagic pleural effusion. Med Princ Pract 2005, 14(2):118-120
22. Hatipoglu CA, Bilgin G, Tulek N, Kosar U: Pulmonary involvement in brucellosis. J Infect 2005, 51(2):116-119.

23. Ohshimo S, Theegarten D, Totsch M, Moege J, Peitgen K, Guzman J, Costabel U: Esophageal sarcoidosis presenting as pseudodiverticulum. Sarcoidosis Vasc Diffuse Lung Dis 2008, 25(1):64-67.

24. Olukman O: Pulmonary involvement in childhood brucellosis: a case report. Vector Borne Zoonotic Dis 2008, 8(2):245-248.

25. Theegarten D, Albrecht S, Totsch M, Teschler H, Neubauer H, Al Dahouk S: Brucellosis of the lung: case report and review of the literature. Virchows Arch 2008, 452(1):97-101.

26. Webb WA, Thoroughman JC: Solitary pulmonary nodule due to Brucella suis. Report of a case. Dis Chest 1966, 49(2):222-224.

27. Park KW, Kim DM, Park CY, Kim HL, Jang SJ, Choi YS, Park MY, Song HJ, Lee SH: Fatal systemic infection with multifocal liver and lung nodules caused by Brucella abortus. Am J Trop Med Hyg 2007, 77(6):1120-1123.

28. Alton GG, Jones LM, Pietz DE: Laboratory techniques in Brucellosis. Monogr Ser World Health Organ 1975, , 55: 1-163.

29. Institute/NCCLS CLSI ed.: Performance standards for antimicrobial susceptibility testing-19th informational supplement-M100-S19 Wayne, PA: CLSI 2009

30. Jevitt LA, Weigel LM, De B, Popovic T, Patel JB: Development of a broth microdilution procedure for antimicrobial susceptibility testing of Brucella spp., abstr. C-357. Abstr. 105th Gen Meet Am soc Microbiol 2005: 2005; Atlanta, GA American Society for Microbiology, Washington, D.C. 2005.

31. Gee JE, De BK, Levett PN, Whitney AM, Novak RT, Popovic T: Use of $16 \mathrm{~S}$ rRNA gene sequencing for rapid confirmatory identification of Brucella isolates. J Clin Microbiol 2004, 42(8):3649-3654.

32. Paquet JY, Diaz MA, Genevrois $\mathrm{S}$, Grayon M, Verger JM, de Bolle X, Lakey JH, Letesson JJ, Cloeckaert A: Molecular, antigenic, and functional analyses of Omp2b porin size variants of Brucella spp. J Bacteriol 2001, 183(16):4839-4847.

33. Scholz HC, Al Dahouk S, Tomaso H, Neubauer H, Witte A, Schloter M, Kampfer P, Falsen E, Pfeffer M, Engel M: Genetic diversity and phylogenetic relationships of bacteria belonging to the OchrobactrumBrucella group by recA and 165 rRNA gene-based comparative sequence analysis. Syst Appl Microbiol 2008, 31(1):1-16.

34. Batchelor BI, Brindle RJ, Gilks GF, Selkon JB: Biochemical mis-identification of Brucella melitensis and subsequent laboratory-acquired infections. The Journal of hospital infection 1992, 22(2):159-162.

35. Elsaghir AA, James EA: Misidentification of Brucella melitensis as Ochrobactrum anthropi by API 20NE. J Med Microbiol 2003, 52(Pt 5):441-442.

36. Cloeckaert A, Grayon M, Grepinet O: An IS711 element downstream of the bp26 gene is a specific marker of Brucella spp. isolated from marine mammals. Clin Diagn Lab Immunol 2000, 7(5):835-839.

37. Halling SM, Tatum FM, Bricker BJ: Sequence and characterization of an insertion sequence, IS711, from Brucella ovis. Gene 1993, 133(1):123-127.

38. Maquart M, Zygmunt MS, Cloeckaert A: Marine mammal Brucella isolates with different genomic characteristics display a differential response when infecting human macrophages in culture. Microbes and infection/ Institut Pasteur 2009, 11(3):361-366.

39. Gurtler V, Mayall BC: Genomic approaches to typing, taxonomy and evolution of bacterial isolates. Int J Syst Evol Microbiol 2001, 51(Pt 1):3-16

40. Thompson CC, Thompson FL, Vandemeulebroecke K, Hoste B, Dawyndt P, Swings J: Use of recA as an alternative phylogenetic marker in the family Vibrionaceae. Int J Syst Evol Microbiol 2004, 54(Pt 3):919-924.

41. Scholz HC, Tomaso H, Dahouk SA, Witte A, Schloter M, Kampfer P, Falsen E, Neubauer H: Genotyping of Ochrobactrum anthropi by recA-based comparative sequence, PCR-RFLP, and 16S rRNA gene analysis. FEMS Microbiol Lett 2006, 257(1):7-16.

42. Cloeckaert A, Grayon M, Verger JM, Letesson JJ, Godfroid F: Conservation of seven genes involved in the biosynthesis of the lipopolysaccharide Oside chain in Brucella spp. Res Microbiol 2000, 151(3):209-216.

43. Cloeckaert A, Grepinet O, Salih-Alj Debbarh H, Zygmunt MS: Overproduction of the Brucella melitensis heat shock protein DnaK in Escherichia coli and its localization by use of specific monoclonal antibodies in B. melitensis cells and fractions. Res Microbiol 1996, 147(3):145-157.

44. Cloeckaert A, Jacques I, Grillo MJ, Marin CM, Grayon M, Blasco JM, Verger JM: Development and evaluation as vaccines in mice of Brucella melitensis Rev. 1 single and double deletion mutants of the bp26 and 
omp31 genes coding for antigens of diagnostic significance in ovine brucellosis. Vaccine 2004, 22(21-22):2827-2835.

45. Cloeckaert A, Verger JM, Grayon M, Grepinet O: Restriction site polymorphism of the genes encoding the major $25 \mathrm{kDa}$ and $36 \mathrm{kDa}$ outer-membrane proteins of Brucella. Microbiology 1995, 141(Pt 9):2111-2121.

46. Kumar S, Nei M, Dudley J, Tamura K: MEGA: a biologist-centric software for evolutionary analysis of DNA and protein sequences. Brief Bioinform 2008, 9(4):299-306.

47. Whatmore AM, Perrett LL, MacMillan AP: Characterisation of the genetic diversity of Brucella by multilocus sequencing. BMC Microbiol 2007, 7:34.

48. Huynh LY, Van Ert MN, Hadfield T, Probert WS, Bellaire BH, Dobson M, Burgess RJ, Weyant RS, Popovic T, Zanecki S, et al: Multiple Locus Variable Number Tandem Repeat (VNTR) Analysis (MLVA) of Brucella spp. identifies species specific markers and insights into phylogenetic relatiohsips. National Institute of Allergy and Infectious Disease, NIH: Frontiers in Research 2008.

49. Tiller RV, De BK, Boshra M, Huynh LY, Van Ert MN, Wagner DM, Klena J, MT S, El-Shafie SS, Keim P, et al: Comparison of two multiple locus variable number tandem repeat (VNTR) analysis (MLVA) methods for molecular strain typing human Brucella melitensis isolates from the Middle East. Journal of Clinical Microbiology 2009, 47(7):2226-2231.

doi:10.1186/1471-2180-10-23

Cite this article as: Tiller et al:: Identification of an unusual Brucella strain (BO2) from a lung biopsy in a 52 year-old patient with chronic destructive pneumonia. BMC Microbiology 2010 10:23.

\section{Submit your next manuscript to BioMed Central and take full advantage of:}

- Convenient online submission

- Thorough peer review

- No space constraints or color figure charges

- Immediate publication on acceptance

- Inclusion in PubMed, CAS, Scopus and Google Scholar

- Research which is freely available for redistribution

Submit your manuscript at www.biomedcentral.com/submit 